\title{
Initial water repellency affected organic matter depletion rates of manure amended soils in Sri Lanka
}

\author{
D.A.L. Leelamanie
}

Department of Soil Science, Faculty of Agriculture, University of Ruhuna, Mapalana, Kamburupitiya 81100, Sri Lanka. Tel.: +94-71-861-4380. Fax: +94-41-2292384. E-mail: leelamanie@soil.ruh.ac.lk, leelamaniee@yahoo.co.uk

\begin{abstract}
The wetting rate of soil is a measure of water repellency, which is a property of soils that prevents water from wetting or penetrating into dry soil. The objective of the present research was to examine the initial water repellency of organic manure amended soil, and its relation to the soil organic matter (SOM) depletion rates in the laboratory. Soil collected from the Wilpita natural forest, Sri Lanka, was mixed with organic manure to prepare soil samples with 0 , 5 , 10,25 , and $50 \%$ organic manure contents. Locally available cattle manure (CM), goat manure (GM), and Casuarina equisetifolia leaves (CE) were used as the organic manure amendments. Organic matter content of soils was measured in $1,3,7,14$, and 30 days intervals under the laboratory conditions with $74 \pm 5 \%$ relative humidity at $28 \pm 1^{\circ} \mathrm{C}$. Initial water repellency of soil samples was measured as the wetting rates using the water drop penetration time (WDPT) test. Initial water repellency increased with increasing SOM content showing higher increasing rate for hydrophobic CE amended samples compared with those amended with CM and GM. The relation between water repellency and SOM content was considered to be governed by the original hydrophobicities of added manures. The SOM contents of all the soil samples decreased with the time to reach almost steady level at about $30 \mathrm{~d}$. The initial SOM depletion rates were negatively related with the initial water repellency. However, all the CE amended samples initially showed prominent low SOM depletion rates, which were not significantly differed with the amended manure content or the difference in initial water repellency. It is explicable that the original hydrophobicity of the manure as well has a potentially important effect on initiation of SOM decomposition. In contrast, the overall SOM depletion rate can be attributed to the initial water repellency of the manure amended sample, however, not to the original hydrophobicity of the amended manure. Hydrophobic protection may prevent rapid microbial decomposition of SOM and it is conceivable that hydrophobic substances in appropriate composition may reduce organic matter mineralization in soil. These results suggest the contribution of hydrophobic organic substances in bioresistance of SOM and their long-term accumulation in soils.
\end{abstract}

Keywords: Carbon mineralization; Hydrophobicity; Organic manure; Water drop penetration time; Water repellency.

\section{INTRODUCTION}

Soil water repellency (hydrophobicity) is a phenomenon that prohibits water from wetting or infiltrating into dry soil. A hydrophobic soil can resist wetting for periods ranging from a few seconds to days or even months. A vast amount of data on water repellency has been documented for soils from different regions, climates, soil types and land uses around the world (DeBano, 2000; Doerr et al., 2006; Jaramillo et al., 2000; Lichner et al., 2012, 2013; Leelamanie and Karube 2014a, 2014b; Wallis and Horne, 1992). Water repellency of soils is identified to be affected by various biotic and abiotic factors. Wildfires, soil texture, soil moisture, and temperature are some of the abiotic factors (Doerr et al., 2000, 2006), whereas the presence of hydrophobic organic compounds released by roots and plant tissues, fungal and algae activity, and the mineralization rates of organic matter are the biotic factors (Doerr et al., 2006; Goebel et al., 2009, 2011; Lichner et al., 2007, 2013; Savage et al., 1972).

One option to mitigate global climate change caused by elevated atmospheric $\mathrm{CO}_{2}$ is to improve the capacity of soil to act as a carbon sink (Lal et al., 2007), which may be achieved through reduced mineralization of organic carbon in soils. In the current climate change predictions, soil carbon and climate change relations show remarkable uncertainties, primarily because soil carbon models basically depend on the assumption that all soil carbon reacts equally to climate warming (Cox et al., 2000; Jones et al., 2005). However, decomposition of differ- ent organic substrates entailed with differing activation energies and temperature sensitivities (Davidson and Janssens, 2006).

In general, the rate of decomposition of organic matter depends primarily on the soil temperature, moisture, and aeration. Cooler areas have higher levels of soil organic matter (SOM) because of lower decomposition rates. The SOM content in tropical areas is comparatively low due to continuous high temperatures and high relative humidities supporting rapid decomposition. The specific moisture status of soils can be regarded as a key factor controlling the decomposition of SOM (Marschner and Kalbitz, 2003). Three processes are identified as being potentially important for microbial decomposition of SOM: (i) water infiltration into the soil, (ii) water distribution within the soil matrix and (iii) microscopic arrangement of water on particle surfaces (Goebel et al., 2011). Soil water repellency affects soil water content, the distribution of water in soil, preferential flow patterns, sorption of solutes, water film thickness in unsaturated soil (Bauters et al., 1998; Derjaguin and Churaev, 1986; Kobayashi et al., 2007; Lichner et al., 2013), and consequently potentially all processes in soil where water is involved (de Jonge et al., 1999). This in turn can diminish the microbial decomposition of SOM. In addition, the reduced infiltration capacity act in favor of the protection of aggregates (Leelamanie et al., 2013), enhancing the stability of occluded SOM. Alternatively, reduced infiltration capacity enhances surface runoff and soil erosion, which can intensify the mineralization of formerly protected SOM (Goebel et al., 2011 and references therein). 
In addition to the use in conventional farming, organic amendments and fertilizers are being increasingly utilizing with the development of organic farming (Hartz et al., 2000). Huge demand for such organic amendments is prominent as a result of the social need for healthy food and the constant legislative pressure for recycling of organic wastes. Both farmers and environmental scientists need more precise parameters for understanding the mineralization of such added organic matter in amended soils. The stocks of organic matter in soils are determined by the balance between inputs and outputs of carbon within the belowground environment. Inputs are primarily from plant and animal detritus, whereas the outputs are the efflux of carbon dioxide and methane from the soil surface, and hydrologic leaching of carbonic compounds.

Literature reports many works that have dealt with decomposition of carbon and nitrogen in crop residues (Janzen and Kucey, 1988; Kaboneka et al., 1997; Mary et al., 1993; Recous et al., 1995). However, mineralization kinetics of organic carbon in manure amended soils in relation to the water repellency is still to be explored in detail. Laboratory protocols differ on many components such as environmental temperature, amount of amended manure, and decomposition of amended manure alone (specific mineralization) (Thuriès et al., 2001), where the inputs of carbon are restricted.

The objective of the present research was to examine the relation of initial water repellency to organic matter depletion rates of soils amended with organic manures with organic matter content ranging from low to high under standard laboratory conditions. For this purpose, organic manures of plant and animal origin (two locally available animal manures that are commonly in use and one hydrophobic green manure) that having different hydrophobicities were used as organic amendments for soil, and the original hydrophobicity of organic amendments and initial water repellency of manure amended soils were related to the organic matter depletion rate of the soils.

\section{MATERIALS AND METHODS}

Soils were taken from the Wilpita Natural Forest in Matara District, located in the low country wet zone of Sri Lanka

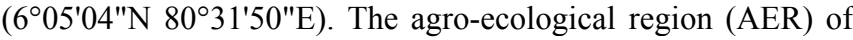
the area is WL2a, according to the National Atlas of Sri Lanka (2007). The region has a tropical climate with an expected annual precipitation ranging from 2400 to $2800 \mathrm{~mm}$. The mean annual temperature of the area is $28^{\circ} \mathrm{C}$ ranging from a minimum of $22-24^{\circ} \mathrm{C}$ in December-February to a maximum of $32-35^{\circ} \mathrm{C}$ March-May. The relative humidity $(\mathrm{RH})$ during the day time is $60-75 \%$ and the nighttime is about $90 \%$ (National Atlas of Sri Lanka, 2007). The soil is locally known to be red yellow podzolic soils (USDA classification: Udults) are the most widespread great soil group in the wet zone of Sri Lanka. The basic properties of the soil are presented in Table 1 .

Soil was thoroughly air dried to a constant weight under the laboratory conditions $\left(74 \pm 5 \%\right.$ relative humidity at $\left.28 \pm 1^{\circ} \mathrm{C}\right)$, while braking natural aggregates by gently pressing them with a spatula during drying, and passed through $2 \mathrm{~mm}$ sieve to eliminate coarse soil particles before soil analysis. Three different types of organic manure, namely, cattle manure (CM), goat manure (GM), and Casuarina (Casuarina equisetifolia) leaves (CE) (Faculty of Agriculture, University of Ruhuna, Sri Lanka), were used as the soil amendments. Thoroughly air dried organic manures were grinded using a mechanical grinder, sieved separately with $1 \mathrm{~mm}$ sieve and mixed with soil in 5 percentages
Table 1. Basic properties of soil.

\begin{tabular}{lc}
\hline Property & value \\
\hline Bulk density $\left(\mathrm{Mg} \mathrm{m}^{-3}\right)$ & 1.25 \\
Particle density $\left(\mathrm{Mg} \mathrm{m}^{-3}\right)$ & 2.60 \\
Porosity (\%) & 51.9 \\
Sand (\%) & 65.0 \\
Silt (\%) & 12.5 \\
Clay (\%) & 22.5 \\
Organic matter content $\left({\left.\mathrm{g} 100 \mathrm{~g}^{-1}\right)}_{\mathrm{pH}}\right.$ & 1.05 \\
EC $\left(\mathrm{mS} \mathrm{m}^{-1}\right)$ & 4.9 \\
$\mathrm{CEC}\left(\mathrm{cmol}_{\mathrm{c}} \mathrm{kg}^{-1}\right)$ & 3.0 \\
\hline
\end{tabular}

$(0,5,10,25$, and $50 \%)$. Unadulterated organic manure $(100 \%$ $\mathrm{CE}, \mathrm{CM}$, and GM) were prepared to test the original hydrophobicity of the materials. The average water contents of the samples during the experimental period of $30 \mathrm{~d}$ were within the range of 1.00-2.00 g $100 \mathrm{~g}^{-1}$, and did not show any significant variation with time.

The water repellency of soil samples and amended manures was measured as the relative wetting rates using the water drop penetration time (WDPT) test. About $5 \mathrm{~g}$ of air-dried samples, in 3 replicates, was taken to weighing bottles with $30 \mathrm{~mm}$ in diameter and height. The bottles were tapped gently to provide homogeneous packing of the sample inside the weighing bottles and to obtain evenly flat surface condition. As this procedure might bring courser materials to the surface, care was taken to limit the tapping to only three times. The dry bulk density of the samples inside the weight bottle varied corresponding to the amount of added organic matter in the sample $\left(\sim 1.4 \mathrm{Mg} \mathrm{m}^{-3}\right.$ in samples without organic matter; $\sim 0.5 \mathrm{Mg} \mathrm{m}^{-3}$ in samples with $50 \% \mathrm{CE}$ ). One drop of distilled water with $50 \pm 1 \mu \mathrm{L}$ of volume was placed on the soil surface with a burette at about $10-\mathrm{mm}$ height, an impartial level designated to avoid soil-water interactions of intact droplets and excess kinetic energy effects of falling droplets. The time taken for the complete penetration of the water drop was measured using a stopwatch (King 1981; Leelamanie and Karube, 2007). The shortest measurable penetration time was $0.2 \sim 0.3 \mathrm{~s}$ corresponding to the instantaneous penetration of water drops, whereas the longest time was $7200 \mathrm{~s}$ as the measurements were terminated after $2 \mathrm{~h}$. Where the penetration times exceeded $60 \mathrm{~s}$, weighing bottles with samples were covered with lids to minimize evaporation losses from water droplets. Measurements for all the samples were taken in triplicates, as initial (1 d) and intermediary hydrophobicities $(3,7$, 14 , and $30 \mathrm{~d}$ ).

The organic matter content of samples was measured colorimetrically using dichromate oxidation of organic carbon (Nelson and Sommers, 1996) and loss on ignition method (400$440^{\circ} \mathrm{C}, 6 \mathrm{~h}$ ). Measurements for SOM content were taken at 1,3 , 7,14 , and $30 \mathrm{~d}$.

All the experiments were conducted in laboratory conditions at $28 \pm 1{ }^{\circ} \mathrm{C}$ with $75 \pm 5 \% \mathrm{RH}$. Data were statistically analyzed using STATISTICA software (Statsoft Inc., 2010), with analysis of variance (ANOVA) at $5 \%$ level of significance $(p<0.05)$. Error bars in the figures represent \pm standard deviation.

\section{RESULTS AND DISCUSSION}

The water repellency, as measured by WDPT, showed positive linear correlation to the SOM content of the sample 

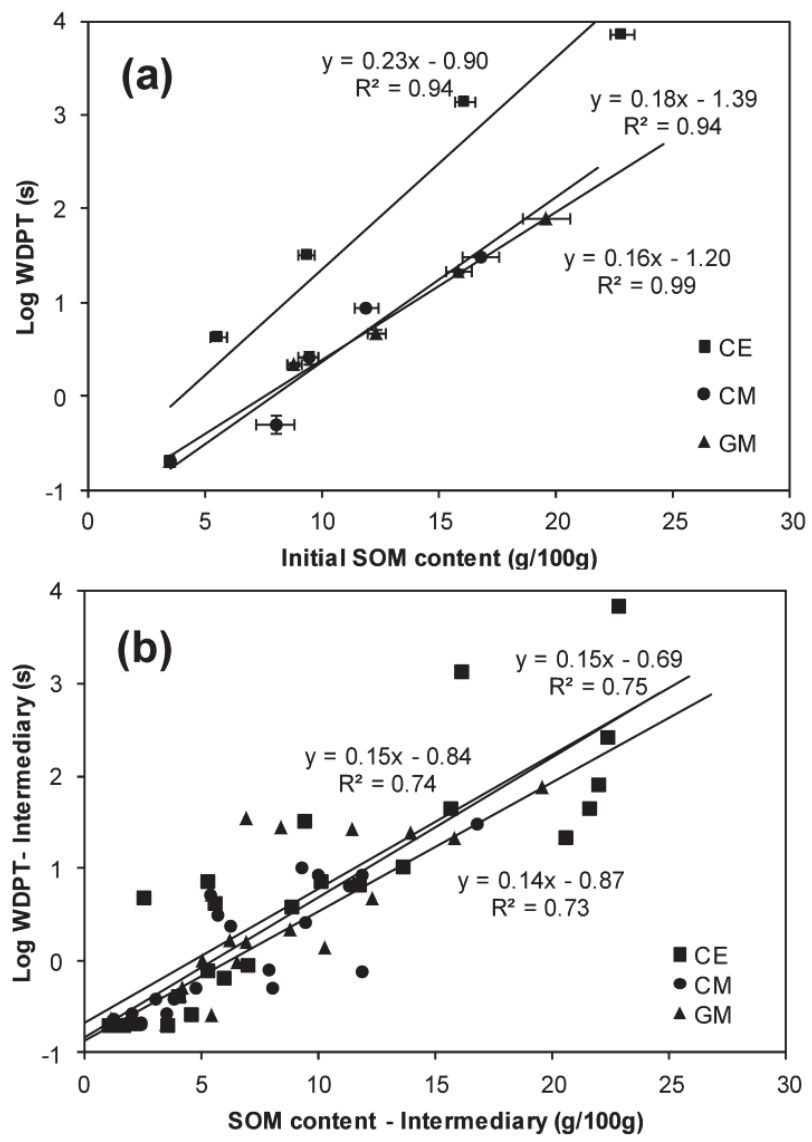

Fig. 1. Relation of laboratory measured (a) initial soil organic matter (SOM) content to the initial hydrophobicity and (b) intermediary SOM contents to intermediary hydrophobicities (measured during the $30 \mathrm{~d}$ experimental period) of samples amended with organic manures as measured by water drop penetration time (WDPT). Error bars represent \pm standard deviation. CE: Casuarina equisetifolia leaves; CM: cattle manure; GM: goat manure.

regarding both initial and intermediary levels during the experimental period (Figure 1). The control sample (no amended manure) was readily wettable (WDPT $<1$ s) throughout the experimental period. Intermediary log WDPT measured with time $(1-30$ d) decreased with decreasing SOM content (corresponding to the decomposition of SOM) showing no significant differences among the types of the amended manure $\left(\mathrm{R}^{2}=\sim 0.7\right)$ (Figure $\left.1 \mathrm{~b}\right)$.

The initial log WDPT increased with increasing SOM content (corresponding to the amount of added manure) showing positive linear correlation $\left(\mathrm{R}^{2}=0.94-0.99\right)$ (Figure 1a). The slope of the linear regression line (Microsoft Excel 2010) was 28-44\% steeper for CE amended samples compared with those amended with CM and GM. The CE amended samples showed significantly higher $(\mathrm{p}<0.05)$ water repellency values at the same SOM content compared with those amended with $\mathrm{CM}$ and

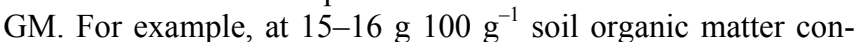
tent, the WDPT of CE amended samples was about $1400 \mathrm{~s}$ (log WDPT 3.14) compared with 20-30 s WDPTs (log WDPT 1.331.47) in samples amended with CM and GM.

Results clearly revealed that soils amended with CE obtained higher initial water repellency compared with those amended with CM and GM (Figure 1a). This can be considered as governed by the original hydrophobicities of added manures.
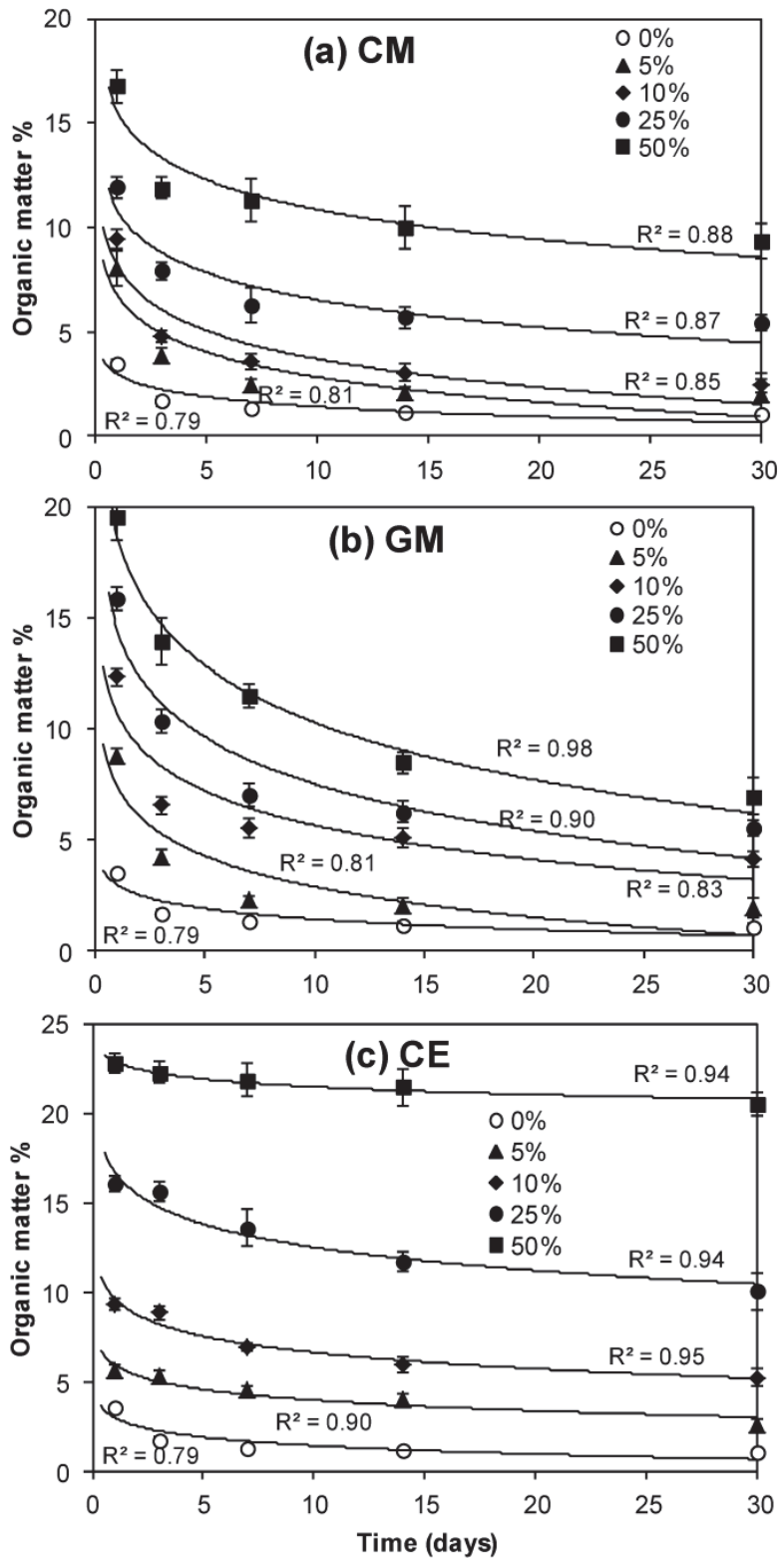

Fig. 2. Decrease in soil organic matter (SOM) content with time in soil samples treated with organic manures. Error bars represent \pm standard deviation. CE: Casuarina equisetifolia leaves; CM: cattle manure; GM: goat manure.

Among the organic amendments used in this study, CE has the highest original hydrophobicity (WDPT $>3 \mathrm{~h}$ for $100 \% \mathrm{CE}$ ) compared with other two amendments (WDPT $=3-5 \mathrm{~min}$ for $100 \% \mathrm{CM}$ and $\mathrm{GM}$ ). This caused $\mathrm{CE}$ amended samples to show high increasing rate of water repellency with increasing SOM content in comparison with samples amended with CM and GM.

The SOM contents of all the soil samples decreased with time (Figure 2). Comparatively high SOM depletion rates were initially observed for all the samples, where this rate gradually decreased with time to reach almost steady level at about $30 \mathrm{~d}$. As shown in Figure 2a, b, c, initial organic matter depletion rates were similar in samples amended with $\mathrm{GM}$ and $\mathrm{CM}$, whereas very low rates were observed with those amended with CE. 

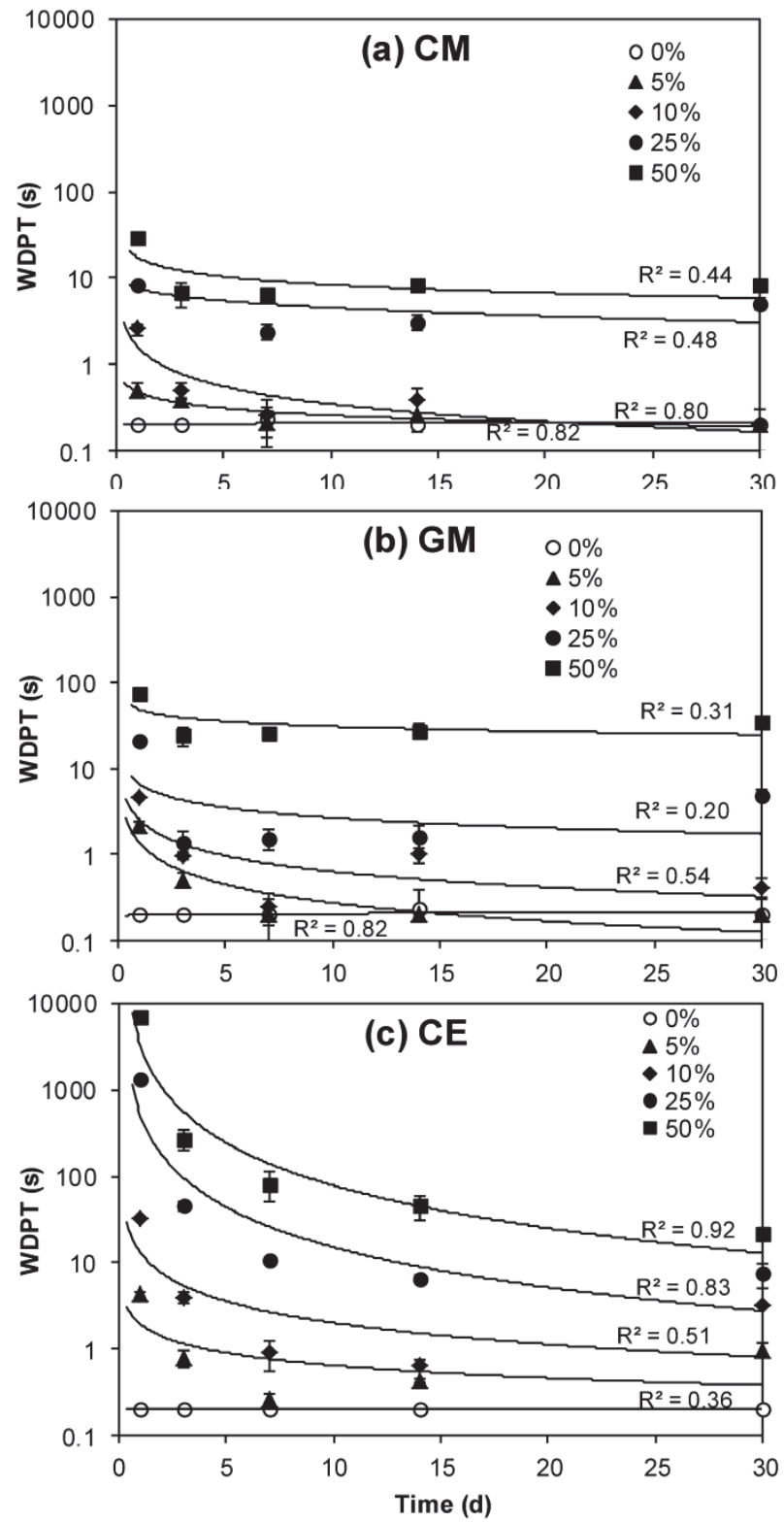

Fig. 3. Decrease in water repellency with time as measured by water drop penetration time (WDPT) in soil samples treated with organic manures. Error bars represent \pm standard deviation. CE: Casuarina equisetifolia leaves; CM: cattle manure; GM: goat manure.

The average water contents of the samples during the experimental period of $30 \mathrm{~d}$ were within the range of 1.00

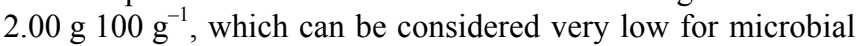
decomposition. However, there are some evidences in literature confirming that microbial activity cannot be considered negligible under air dried conditions, where microbes sometimes are active in very dry soils with water potentials around $-3.0 \mathrm{MPa}$ (Cregger et al., 2014; Whitford, 1996).

Decrease in water repellency with time as measured by water drop penetration time (WDPT) in soil samples treated with organic manures is presented in Figure 3. Clear decrease in water repellency was observed in samples amended with CE.

Initial depletion rate of SOM from 1 to 3 days for the samples amended with organic manures in relation to the added amounts of organic manure and initial water repellency are respectively presented in Figure $4 a$ and $b$. The initial organic
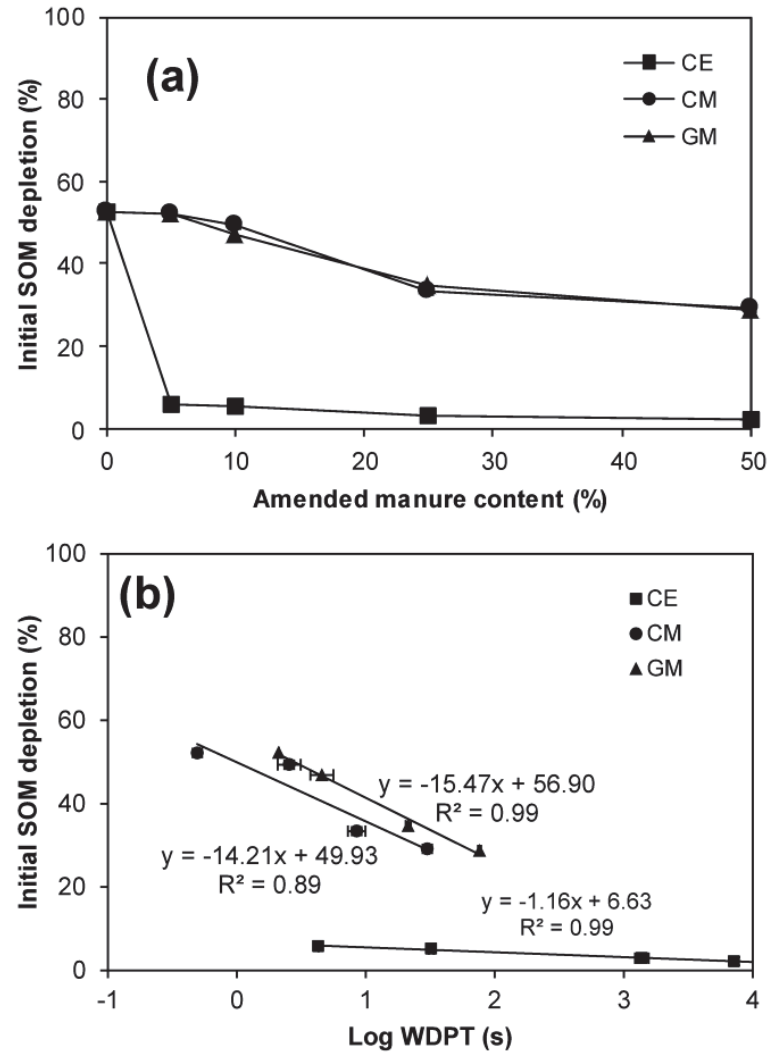

Fig. 4. Initial depletion rate of soil organic matter (SOM) from 1 to 3 days for the samples amended with organic manures in relation to the (a) added amounts of organic manure and (b) initial hydrophobicity. Error bars in (b) represent \pm standard deviation. CE: Casuarina equisetifolia leaves; CM: cattle manure; GM: goat manure; WDPT: water drop penetration time.

matter depletion rate decreased with addition of organic manure (Figure 4a). This effect was most prominent in samples amended with CE. The initial SOM depletion rate, which was nearly $52 \%$ in the control sample (no amended manure), decreased to be about $5 \%$ with the addition of $5 \%$ CE. As shown in Figure $4 \mathrm{~b}$, the initial SOM depletion rates were negatively related with the initial water repellency. However, evident low initial SOM depletion rates were observed for CE amended samples. Irrespective of the initial water repellency, all the CE amended samples showed significantly low SOM depletion rates, which were not significantly differed with the amended manure content or the difference in water repellency. Besides the initial water repellency, there have to be some other factor/s that appear to control SOM depletion rates of the manure amended samples. It is explicable that the original hydrophobicity of the manure has a potentially important effect on initiation of SOM decomposition in the amended samples. According to chemical kinetic theory, decomposition of recalcitrant organic substrates has higher activation energy (Karhu et al., 2010, and references therein). Hydrophobic organic compounds that are considered to be recalcitrant (González-Pérez et al., 2002) would require higher activation energy, and thereby can slow down the initiation of the organic matter decomposition process in originally hydrophobic CE amended samples. Considering these facts, the initial SOM depletion rate may be attributed to the initial water repellency of the manure amended sample as well as to the original hydrophobicity of the amended manure. 
The relation of overall organic matter depletion rate (within the $30 \mathrm{~d}$ experimental period) to the initial water repellency of the samples was determined considering both the overall organic matter depletion percentage and the slopes of organic matter depletion curves (Figure 5). Overall organic matter depletion during the period of $30 \mathrm{~d}$ was determined as a percentage of the initial organic matter content. The dropping slopes of the lines were computed with Linear Regression by fitting a line to $\mathrm{LN}(x), \mathrm{LN}(y)$ using LINEST (Microsoft Excel 2010), which calculates the statistics for the line by using the least squares method considering the following equation:

$\mathrm{LN}(y)=\mathrm{LN}(x) \times m+\mathrm{LN}(b)$

where $y$ is the organic matter content, $x$ is the time, $b$ is the intercept, and $m$ is the slope of the line. As presented in Figure $5 \mathrm{a}$, the overall SOM depletion percentage of the samples showed negative linear correlation with initial water repellency of samples $\left(\mathrm{R}^{2}=0.77\right)$. In contrast to the initial SOM depletion rate, substantial variations in the overall SOM depletion percentage were not observed among the types of amended manure. Likewise, the natural logarithmic slopes of the organic matter depletion curves also showed negative linear correlation with initial hydrophobicities of the samples $\left(\mathrm{R}^{2}=0.67\right)$ deprived of substantial disparities among manure types. Consequently, the overall SOM depletion rate can be attributed to the initial water repellency of the manure amended sample, however, not to the original hydrophobicity of the amended manure.
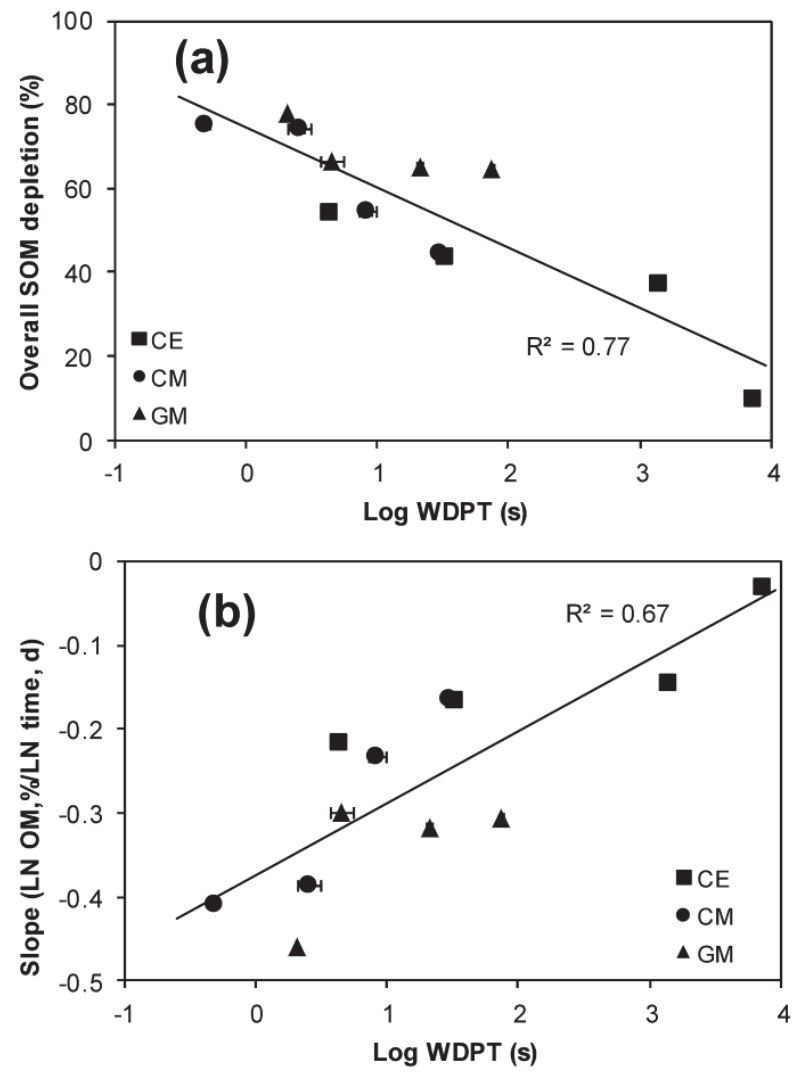

Fig. 5. The relation of initial hydrophobicity (a) to the overall soil organic matter (SOM) depletion rate (within the $30 \mathrm{~d}$ experimental period) and (b) to the slopes of organic matter depletion curves of the samples. Error bars represent \pm standard deviation. CE: Casuarina equisetifolia leaves; CM: cattle manure; GM: goat manure; WDPT: water drop penetration time.
According to the results, both initial and overall SOM mineralization rates can be considered to show a negative relation with the level of water repellency of the soil. This is in agreement with Goebel et al. (2007) who suggested that the water repellency level of the soil affects the decay rate of SOM mineralization. We further suggest that the original hydrophobicity of the added manure might also play an important role in initial SOM mineralization rates. The SOM contents decreased (Figure 2) and the water repellency showed a decreasing trend (Figure 3) with time. When correlated to the intermediary SOM contents, intermediary water repellency showed a decreasing trend with decreasing SOM content of the sample (Figure 1b). Accordingly, intermediary water repellency cannot be negatively related to the OM decomposition, although the initial water repellency and the original hydrophobicity of the manure can be considered to show negative correlation. Therefore, it is clear that intermediary hydrophobicities of the samples do not play a significant role in governing the SOM decomposition process.

Organic compounds can be physically protected from decomposition by water-soluble enzymes if they have low water solubility or if they occur in hydrophobic domains of humified organic matter (Spaccini et al., 2002). Investigation on SOM dynamics shows the evidence that the most recalcitrant humic fractions mainly contain aliphatic compounds (Almendros et al., 1998; Augris et al., 1998). Furthermore, hydrophilic components released from biodegrading plant tissues, which are sequestered in the hydrophobic domains of humus, seems to be protected from further degradation (Spaccini et al., 2000). These results suggest that there is an essential contribution of multiple hydrophobic interactions among organic substances in bioresistance of SOM and their long-term accumulation in soils.

\section{CONCLUSIONS}

Initial water repellency increased with increasing SOM content showing higher increasing rate for hydrophobic $\mathrm{CE}$ amended samples compared with those amended with CM and GM. The relation between water repellency and SOM content was considered to be governed by the original hydrophobicities of added manures.

The SOM contents decreased with the time to reach almost steady level within about $30 \mathrm{~d}$. The initial organic matter depletion rate decreased with addition of organic manure, most prominently in samples amended with CE. The initial SOM depletion rates were negatively related with the initial water repellency. However, all the CE amended samples initially showed significantly low SOM depletion rates, irrespective of the amended manure content or the difference in initial water repellency. It is explicable that the original hydrophobicity of the manure has a potentially important effect on initiation of SOM decomposition in the amended samples. This can be attributed to the requirement of higher activation energy for the beginning of the organic matter decomposition process of in originally hydrophobic $\mathrm{CE}$ amended samples. In contrast to the initial SOM depletion, the overall SOM depletion rate can be attributed to the initial water repellency of the manure amended sample, however, not to the original hydrophobicity of the amended manure. Intermediary water repellency did not show a negative relation with the SOM decomposition, although the initial water repellency and the original hydrophobicity of the manure can be considered to show negative correlation. Therefore, it is clear that intermediary hydrophobicities of the samples do not play a significant role in governing the SOM decomposition process. 
Hydrophobic protection may prevent rapid microbial decomposition of SOM and it is conceivable that hydrophobic substances in appropriate composition may reduce organic matter mineralization in soil. These results suggest the contribution of hydrophobic organic substances in bioresistance of SOM and their long-term accumulation in soils.

Acknowledgement. This work was financially supported by the annual research fund of the Faculty of Agriculture, University of Ruhuna, Sri Lanka.

\section{REFERENCES}

Almendros, G., Guadalix, M.E., González-Vila, F.J., Martin, F., 1998. Distribution of structural units in humic substances as revealed by multi-step selective degradation and 13C-NMR of successive residues. Soil Biol. Biochem., 30, 755-765.

Augris, N., Balesdent, J., Mariotti, A., Derenne, S., Largeau, C., 1998. Structure and origin of insoluble and non-hydrolizable, aliphatic organic matter in a forest soil. Organic Geochemistry, 28, 119-124.

Bauters, T.W.J., DiCarlo, D.A., Steenhuis, T.S., Parlange, J.-Y., 1998. Preferential flow in water-repellent sands. Soil Sci. Soc. Am. J., 62, 1185-1190.

Cox, P.M., Betts, R.A., Jones, C.D., Spall, S.A., Totterdell, I.J., 2000. Acceleration of global warming due to carbon-cycle feedbacks in a coupled climate model. Nature, 408, 184-187.

Cregger, M.A., Sanders, N.J., Dunn, R.R., Classen, A.T., 2014. Microbial communities respond to experimental warming, but site matters. PeerJ 2:e358, doi.org/10.7717/peerj.358

Davidson, E.A., Janssens, I.A., 2006. Temperature sensitivity of soil carbon decomposition and feedbacks to climate change. Nature, 440, 165-173.

de Jonge, L.W., Jacobsen, O.H., Moldrup, P., 1999. Soil water repellency: effects of water content, temperature, and particle size. Soil Sci. Soc. Am. J., 63, 437-442.

DeBano, L.F., 2000. Water repellency in soils: a historical overview. J. Hydrol., 231-232, 4-32.

Derjaguin, B., Churaev, N., 1986. Properties of water layers adjacent to interfaces. In: Croxton, C.A. (Ed.): Fluid Interfacial Phenomena. Wiley, New York, pp. 663-738.

Doerr, S.H., Shakesby, R.A., Walsh, R.P.D., 2000. Soil water repellency: its causes, characteristics and hydrogeomorphological significance. Earth-Sci. Rev., 51, 33-65.

Doerr, S.H., Shakesby, R.A., Dekker, L.W., Ritsema, C.J., 2006. Occurrence, prediction and hydrological effects of water repellency amongst major soil and land-use types in a humid temperate climate. Eur. J. Soil Sci., 57, 741-754.

Goebel, M-O, Woche, S.K., Bachmann, J., Lamparter, A., Fischer, W.R., 2007. Significance of wettability-induced changes in microscopical water distribution for soil organic matter decomposition. Soil Sci. Soc. Am. J., 71, 1593-1599.

Goebel, M.-O., Woche, S.K., Bachmann, J., 2009. Do soil aggregates really protect encapsulated organic matter against microbial decomposition? Biologia, 64, 443-448.

Goebel, M.-O., Bachmann, J., Reichstein, M., Janssens, I.A., Guggenberger, G., 2011. Soil water repellency and its implications for organic matter decomposition - is there a link to extreme climatic events? Glob. Change Biol., 17, 2640 2656.

González-Pérez, J.A., González-Vila, F.J., Polvillo, O., Almendros, G., Knicker, H., Salas, F., Costa, J.C., 2002. Wildfire and black carbon in Andalusian Mediterranean forest. In: Viegas, D.X. (Ed.): Forest Fire Research and Wildland Fire Safety. Millpress, Rotterdam, The Netherlands, pp. 1-7.
Hartz, T.K., Mitchell, J.P., Giannini, C., 2000. Nitrogen and carbon mineralization dynamics of manures and composts. HortScience, 35, 209-212.

Janzen, H.H., Kucey, R.M.N., 1988. C, N and S mineralization of crop residue as influenced by crop species and nutrient regime. Plant and Soil, 100, 35-41.

Jaramillo, D.F., Dekker, L.W., Ritsema, C.J., Hendrickx, J.M.H., 2000. Occurrence of soil water repellency in arid and humid climates. J. Hydrol., 231, 105-111.

Jones, C., McConnell, C., Coleman, K., Cox, P., Falloon, P., Jenkinson, D., Powlson, D., 2005. Global climate change and soil carbon stocks; predictions from two contrasting models for the turnover of organic carbon in soil. Global Change Biology, 11, 54-166.

Kaboneka, S., Sabbe, W.E., Mauromoustakos, A., 1997. Carbon decomposition kinetics and nitrogen mineralization from corn, soybean, and wheat residues. Communications in Soil Sci. Plant Anal., 28, 1359-1373.

Karhu, K., Fritze, H., Tuomi, M., Vanhala, P., Spetz, P., Kitunen, V., Liski, J., 2010. Temperature sensitivity of organic matter decomposition in two boreal forest soil profiles. Soil Biol. Biochem., 42, 72-82.

King, P.M., 1981. Comparison of methods for measuring severity of water repellence of sandy soils and assessment of some factors that affect its measurement. Aust. J. Soil Res., 19, 275-285.

Kobayashi, M., Shimizu, T., 2007. Soil water repellency in a Japanese cypress plantation restricts increases in soil water storage during rainfall events. Hydrol. Processes, 21, 2356-2364.

Lal, R., Follett, F., Stewart, B.A., Kimble, J.M., 2007. Soil carbon sequestration to mitigate climate change and advance food security. Soil Science, 172, 943-956.

Leelamanie, D.A.L., Karube, J., 2007. Effects of organic compounds, water content, and clay on water repellency of a model sandy soil. Soil Sci. Plant Nutr., 53, 711-719.

Leelamanie, D.A.L., Karube, J., 2014a. Water stable aggregates of Japanese Andisol as affected by hydrophobicity and drying temperature. J. Hydrol. Hydromech., 62, 2, 97-100.

Leelamanie, D.A.L., Karube, J., 2014b. Surface hydrophobicity of Japanese Andisol and its behavior upon exposure to heat. Soil Sci. Soc. Am. J., 78, 3, 761-766.

Leelamanie, D.A.L., Karube, J., Samarawickrama, U.I., 2013. Stability analysis of aggregates in relation to the hydrophobicity of organic manure for Sri Lankan Red Yellow Podzolic soils. Soil Sci. Plant Nutr., 59, 5, 683-691.

Lichner, L., Hallett, P.D., Feeney, D.S., Dugova, O., Sir, M., Tesar, M., 2007. Field measurement of soil water repellency and its impact on water flow under different vegetation. Biologia, 62, 537-541.

Lichner, L., Holko, L., Zhukova, N., Schacht, K., Rajkai, K., Fodor, N., Sandor, R., 2012. Plants and biological soil crust influence the hydrophysical parameters and water flow in an aeolian sandy soil. J. Hydrol. Hydromech., 60, 4, 309-318.

Lichner, L., Hallett, P.D., Drongová, Z., Czachor, H., Kovacik, L., Mataix-Solera, J., Homolák, M., 2013. Algae influence the hydrophysical parameters of a sandy soil. Catena, 108, 58-68.

Marschner, B, Kalbitz, K., 2003. Controls of bioavailability and biodegradability of dissolved organic matter in soils. Geoderma, 113, 211-235.

Mary, B., Fresneau, C., Morel, J.L., Mariotti, A., 1993. C and N cycling during decomposition of root mucilage, roots and glucose in soil. Soil Biol. Biochem., 25, 1005-1014.

National Atlas of Sri Lanka, 2007. National Atlas of Sri Lanka, 2nd ed., Survey Departmentof Sri Lanka, Colombo, Sri Lanka. 
Nelson, D.V., Sommers, L.E., 1996. Total carbon, organic carbon, and organic matter. In: Sparks, D.L. (Ed.): Methods of Soil Analysis. Part 3: Chemical Methods. Soil Science Society of America, Madison, WI, pp. 539-579.

Recous, S., Robin, D., Darwis, D., Mary, B., 1995. Soil inorganic $\mathrm{N}$ availability: effect on maize residue decomposition. Soil Biol. Biochem., 27, 1529-1538.

Savage, S.M., Heaton, C., Osborn, J., Letey, J., 1972. Substances contributing to fire-induced water repellency in soils. Soil Sci. Soc. Am. Proc., 36, 674-678.

Spaccini, R., Piccolo, A., Haberhauer, G., Gerzabek, M.H., 2000. Transformation of organic matter from maize residues into labile and humic fractions of three European soils as revealed by $13 \mathrm{C}$ distribution and CPMAS-NMR spectra. Eur. J. Soil Sci., 51, 583-594.
Spacini, R., Piccolo, A., Conte, P., Haberhauer, G., Gerzabek, M.H., 2002. Increased soil organic carbon sequestration though hydrophobic protection by humic substances. Soil Biol. Biochem., 34, 1839-1851.

Thuriès, L., Pansu, M., Feller, C., Herrmann, P., Rémy, J.-C., 2001. Kinetics of added organic matter decomposition in a Mediterranean sandy soil. Soil Biol. Biochem., 33, 9971010.

Wallis, M.G., Horne, D.J., 1992. Soil water repellency. Advances in Soil Science, 20, 91-146.

Whitford, W.G., 1996. The importance of the biodiversity of soil biota in arid ecosystems. Biodiversity \& Conservation, $5,185-195$.

Received 30 May 2014 Accepted 5 September 2014 